\title{
Reading from the Margin: Examining Nahum Tate's vs. Shakespeare's King Lear as Cultural Products
}

\author{
Ribut Basuki \\ Meilinda \\ English Department, Faculty of Letters, Petra Christian University, \\ Siwalankerto 121-131, Surabaya 60236, East Java, Indonesia \\ e-mails: rbasuki@peter.petra.ac.id \\ meilinda@peter.petra.ac.id
}

\begin{abstract}
Nahum Tate's adaptation of Shakespeare's King Lear was so successful in Restoration theatre. Modern critics, however, regard Tate's work as a second class drama which deserves mockery and dismiss it from master narratives of the history of English theatre. Therefore, we examine the 'fields of cultural production' of Shakespeare's and Nahum Tate's King Lear from Shakespeare's time to the present to find out how each period values a certain work of literature. In the discussion, we would like to argue that the shifting 'fields of cultural production' determines the acceptance and rejection of Nahum Tate's King Lear. By analyzing the 'fields of cultural productions' of both plays, we show that Tate's has been excluded from the canonization within modern field of production's discourses because of shifting circles of belief.
\end{abstract}

Key words: cultural production, drama, theatre, Restoration, Elizabethan, circle of belief, traditional, modern

In master narratives of the history of English theatre, the hallmark of the Restoration period (commonly dated from 1600 until well into the eeighteenth century) is usually its comedies, with its peak on the works of William Congreve (1640-1715). Its tragedies are usually mentioned casually. Moreover, unlike the 'flourishing' tragedies of the Elizabethan period-generally represented by Shakespeare's works - that are usually triumphant in making it into the modern canon, Restoration tragedies only make it, at best, into the Restoration canon. From modern-essentialists' perspective, Restoration tragedies do not succeed in the canonization 
probably because, as Brockett (1995) puts it, "(its) dominant mode was 'heroic' tragedy, which, heavily indebted to Spanish and French authors and set in exotic locales, emphasized stories centering around the rival claims of love and honor" (p. 237). They were also influenced theoretically by neoclassicism with its emphasis on "reason, moderation, good taste, deft management, and simplicity" (Hieatt, 1996, p. 7), although it was "always more liberal than the version that prevailed on the continent" (Brockett, 1995, p. 237). Interestingly, to modern critics, Restoration period is more notorious with its dramatists' habit of 'adapting' Elizabethan tragedies, especially Shakespeare's.

One of the 'adaptors' of Shakespeare's plays was Nahum Tate (16521715). Born and educated in Ireland, Nahum Tate entered London theatre world in 1677 and started writing his own plays. In 1680 he turned to 'adapting' Shakespeare including King Lear, Richard II, and Coriolanus (Black in Tate, 1975, p. xiv). Black mentions that Tate's intellectual pattern was John Dryden (p. xiv), who also ‘adapted' Shakespeare’s works. Unlike John Dryden, however, Tate failed to put his name in totalized narratives of the history of English theatre/drama such as that written by Oscar G. Brockett.

Tate's 'adaptation' of King Lear had actually been so successful on Restoration stages until well into the eighteenth century. Black in Tate (1975) notes that eighteenth-century critics repeatedly endorsed Tate's ending (p. xxvi). Modern critics, on the other hand, generally "scorn” Tate for the 'adaptation.' One critic called it a "hodge-podge," another said "(it) invites ridicule and deserves it” (p. xv). Black further states: "Part of Tate's 'offense' is that his version, and revisions of it, kept Shakespeare's from the stage for a century and a half” (p. xv). Tate's ‘adaptation' of King Lear, therefore, is very interesting to discuss. In this paper we will examine Shakespeare's and Nahum Tate's King Lear in the light of Bourdieu's 'field of cultural production'. By examining Shakespeare's and Nahum Tate's King Lear as cultural products, we would argue that the shifting fields of cultural production determines the acceptance and rejection of Nahum Tate's King Lear.

As cultural products, the texts of King Lear which we can access today were created with determining 'capitals' that were operative in the field of cultural production. A field of production is "understood as the system of objective relations between agents or institutions and as the site of the struggle for the monopoly of power to consecrate, in which the value 
of works of art and belief in that value are continuously generated" (Bourdieu, 1993, p. 78). The field of cultural production may overlap with other fields of production such as the economic field (see Johnson in Bourdieu, 1993, pp. 79-80); however, they are not necessarily structured equally and they even work in different logics. Bourdieu even calls the field of cultural production as "the economic world reversed" (p. 29) since the logic of artistic values may contradict with that of the economic values.

There are two kinds of important capitals in the field of cultural production: symbolic capital and cultural capital. "Symbolic capital refers to degree of accumulated prestige, celebrity, consecration or honour and is founded on dialectic of knowledge (connaissance) and recognition (reconnaissance). Cultural capital concerns forms of cultural knowledge, competences or dispositions" (Johnson in Bourdieu, p. 7). The more an artist possesses these capitals, the better is his/her chance to develop and maintain career in a cultural field. Thus, unlike in the logic of the economic field, in the cultural field, material capital does not necessarily count first. An important aspect in the field of cultural production is the "circle of belief" which results in a currency called "authority". Bourdieu contends that authority is not an individual product but a product of relations. He argues that authority "only exists in the relationship with field of production as a whole,” (p. 78) and he further explains:

[It is in relationship] with the artists or writers who belong to his 'stable' - 'a publisher', said one of them, 'is his catalogue' - and with those who do not and would or would not like to; in relationship with the other dealers or publishers who do or do not envy him his painters or writers and are or are not capable of taking them from him' in the relationship with the critics, .. .; in the relationship with his clients and customers, who perceive his 'trademark' with greater or lesser clarity and do or do not place their trust in it. This 'authority' is nothing other than 'credit' with a set of agents who constitute 'connections' whose value is proportionate to the credit they themselves command. It is all too obvious that critics also collaborate with the art trader in the effort of consecration which make the reputation and, at least in the long term, the monetary value of works. . . . Among the makers of the work of art, we must finally include the public, which helps to make its value by appropriating it materially (collectors) or symbolically (audiences, readers), and by objectively or subjectively identifying 
part of its own value with these appropriations. In short, what 'makes reputations' is not . . . this or that 'influential' person, this or that institution, review, magazine, academy, coterie, dealer or publisher; it is not even the whole of what are sometimes called 'personalities of the world of arts and letters'; it is the field of production, ... (p. 78).

The value of a work of art, therefore, depends on the complex web of relationships so that its rise and fall is determined by conditions of these relationships. To understand the value given to Shakespeare's and Tate's King Lear; therefore, is to uncover the intricate web of relationships in drama/theatre productions throughout the history of the theatre in which the play was (re)written and (re)produced.

\section{NAHUM TATE'S VS SHAKESPEARE'S KING LEAR}

King Lear is considered as one of Shakespeare's best tragedies. The narrative revolves around the major character, King Lear, and people around him, namely the three daughters (Goneril, Regan, and Cordelia) and the gentlemen (Kent, Glocester, Edmund, Edgar, etc.). Tate's King Lear, likewise, also revolves around King Lear as the major character. In both versions, the exposition starts with the entrance of Gloucester, Kent, and Edmund (who is written as Bastard by Tate) while they are talking about the king's plan to retire. The plot, then, reveals that before stepping down, King Lear prepares to divide the kingdom into three for his daughters. The king asks the daughters who loves him most, hoping that he will get pleasing answers from his daughters. While the two older sisters are ready to flatter the father, Cordelia, the youngest daughter, does not want to give a flattering answer. The conflicts in the play are then propelled by the king's misunderstanding of his daughters' motives. There is also a sub plot about the Gloucester. The sub-plot which is also interwoven with the main plot is propelled by the rivalry between Earl of Gloucester's illegitimate son, Edmund/Bastard, and the other son, Edgar. Edmund slanders Edgar in front of his father saying that Edgar plans to kill Earl of Gloucester. Just like King Lear, Gloucester also fails to see which son loves him most. However, there are several significant differences in both versions in terms of the form, structure and also the language.

In terms of the form, both plays differ in that Shakespeare's is tragic while Tate's is heroic. In Shakespeare's version, Cordelia is given to King 
of France and dies together with King Lear. Cordelia dies in the hands of Edmund and King Lear dies because of disappointment, loss of Cordelia, and regret. In Tate's version, Cordelia has a heroic love story with Edgar and successfully defends her father's honor. King Lear finally retreats in happiness after restoring the kingdom and Cordelia is crowned Queen. For the subplot, in Shakespeare's version Edgar must flee from the country as a mad man; while in Tate's, he becomes Cordelia's lover. In Tate's there is a heroic love story between Edgar and Cordelia, even though at first Cordelia rejects Edgar's love. He finally wins her heart after saving her from a rape trial mind-mastered by Edmund.

Secondly, from the structure point of view the differences stand in the plot and characterization. For the opening and ending, Shakespeare's starts with the entrance of three gentlemen (Glocester, Kent, and Edmund) and ends with King Lear's death scene. Tate's, on the other hand, opens with a prologue before the entrance of the gentlemen and ends with the triumphant Cordelia and Edgar before it is ended with an epilogue. In the characterization, while in Shakespeare's version there are characters like King of France and Fool, in Tate's version there is no King of France and Fool. The names of the characters are different in both versions. While Shakespeare is direct with the names of the characters, Tate gives aliases instead of real names such as Servant for the Knight, Bastard for Edmund, and The Gent for Oswald. The length of the play in both versions is also different. Tate's version is less 800 lines shorter compared to Shakespeare's (Dobson \& Wells, 2001, p. 247). However, Tate adds two big parts for Cordelia's love story in Act 1 and Act 5. Also, Tate's Cordelia has more lines compared to Shakespeare's, so that as a character, Tate's Cordelia is stronger and more dominant than Shakespeare's.

Thirdly, they differ in language. From the fact that Tate's version is 800 lines shorter, it can be inferred that Tate's lines are more compact. For example, in King Lear's lines when he is asking his daughters, Shakespeare's version is as follows:

LEAR: Meantime we shall express our darkest purpose.

Give me the map there. Know that we have divided

In three our kingdom; and 'tis our fast intent

To shake all cares and business from our age,

Conferring them on younger strengths, while we

Unburdened crawl toward death. Our son of Cornwall. 


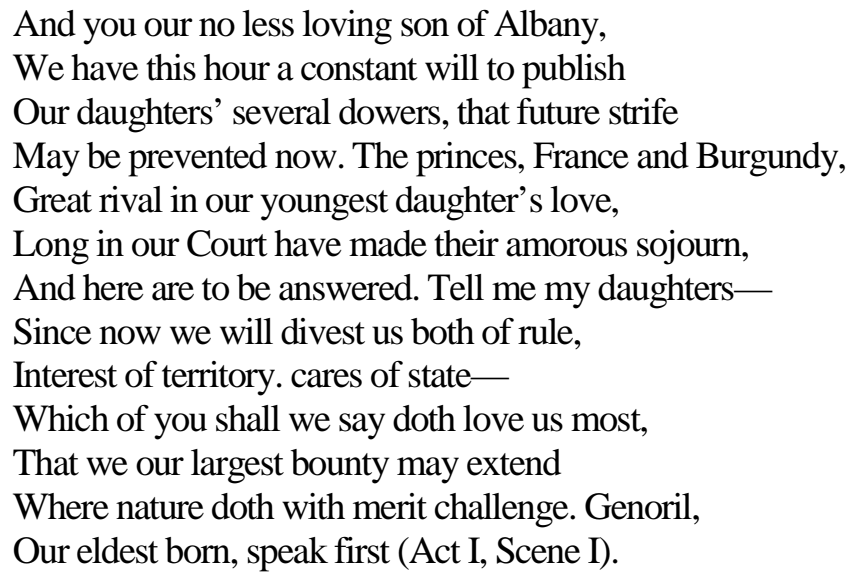

In this dialog, King Lear has nineteen lines, explaining the reason for asking the daughters of who loves him best. For the intention which is said in the last four lines, Shakespeare makes a fifteen-line introduction to make the exposition clear. Nahum Tate, on the other hand, makes this dialog ten lines (thus, omitting nine lines), and makes it straight to the point.

LEAR: Give me the Mapp — know, Lords, We have divided In Three our Kingdom, having now resolved To disengage from Our long Toil of State, Conferring All upon your younger years; You, Burgundy, Cornwall and Albany Long in Our Court have made your amorous sojourn And now are to be answer'd — tell me my Daughters Which of you Loves Us most, that We may place Our largest Bounty with the largest Merit. Gonerill, Our Eldest-born, speak first (Act I).

The real intention is still four lines, but Tate's introduction is only six lines. We can see that in some cases Tate uses Shakespeare's lines, but in others he writes it in his own language. The difference in language, therefore, is that while Shakespeare's sounds more flowery, Tate's is more direct and simple. 


\section{KING LEAR AND THE FIELD CULTURAL PRODUCTION}

To do justice to the values of Nahum Tate's King Lear compared to that of Shakespeare, we cannot rely solely on the traditional construction of the history of Shakespeare or English drama/theatre. There is a need to reexamine any source and scrutinize meanings that have been silenced in the face of the construction of Shakespeare as a giant in the English literature. To do so, in this part we would like to explore the history of the compositions and productions of King Lear and see how the shifting fields of cultural production affect the authorities of the artists.

\section{The Compositions and Productions of King Lear since Elizabethan Period}

Before discussing the compositions and productions of King Lear, it is necessary to examine how Shakespeare's works that we know today were actually composed and produced from time to time. It should be noted that unless somebody reads accounts on Shakespeare carefully, s/he might not notice that Shakespeare did not publish his works himself. This is because historians usually mention it casually so that an important account about the composition of the works may be overlooked. In less than one paragraph, for instance, Brockett (1995) writes:

Like most of his contemporaries, Shakespeare gave little thought to preserving his plays, which in his time were looked upon as momentary diversions (much as television dramas are today). Their survival may be credited in large part to the desire of Shakespeare's fellow actors, especially Henry Condell and John Heminges, to preserve his memory by publishing his plays. (This original edition, which appeared in 1623, is usually referred to as First Folio) (p. 157).

From this account we learn that Shakespeare's plays were not meant to be read as 'literature', but as scripts of theatre productions. One should note, first of all, that scripts, as we will notice in the case of King Lear later, are subject to revisions. Revisions of a script may be done alone by the writer, but it may be done together with the production team. Thus, it is safe to assume that there may be problems on the authenticity of the text. Moreover, secondly, the account says that they first appeared in 1623, thus 
it was seven years after his death in 1616 (p. 156). Condell and Heminges must have done their best as 'editors'. Therefore, we can have a reasonable doubt whether they did not alter anything in the works. To suggest that not all of the texts were really Shakespeare's, Brocket says that “. . . some of them were written in part by others" (p. 156).

The problem of authenticity may be seen more specifically in the composition and production of Shakespeare's King Lear. Dobson and Wells (2001) write about the text of Shakespeare's King Lear as follows:

The play was first printed, badly, in 1608. The origin of this text has been much disputed but the current view is that it derives from Shakespeare's original manuscript. It was reprinted with minor but unauthoritative improvements in 1619. Editors from the early 18th century onwards, assuming that both texts derive from a single archetype, normally conflated them, but recent research indicates that the 1608 quarto represents the play as Shakespeare first wrote it, and the Folio a substantial revision, cutting some 300 lines and adding about 100, and with many other variations (p. 247).

From Dobson and Wells we learn that there have been disputes about the origin of the text. That it is originally from the manuscript of Shakespeare is only a view or opinion. Assuming that all Shakespeare's works are originally his, a layman on Shakespeare may proudly say that he has read Shakespeare's King Lear. However, s/he never knows that there are many texts and what $s /$ he does not realize is that the origin of the text is still disputed.

A clear statement about the problem of Shakespeare's King Lear's authenticity was made by G.R. Hibbard (1982) in a retrospect of the text productions of King Lear in 1939-1979. He writes: “. . . paradoxically enough, there is no general consensus among editors as to what Shakespeare actually wrote; and editions differ greatly from one another in the texts they offer" (p. 1). Hibbard, then, shows examples of some publications that disagree in many lines. He further writes:

The prime cause of the variations is, of course, that there are two substantive texts, not one: the Quarto of 1608, containing some 300 lines not found in the Folio, and the Folio itself, containing 100 lines not found in the Quarto. The editor must, therefore, or has hitherto felt that he must, make use of both while knowing full well, to complicate 
his task still further, that neither of them was set up from a manuscript in Shakespeare's hand (p. 1).

Hibbard continues with the discussion of this messy data and finally quotes somebody as saying: "[It] can only lead to the conclusion . . . that King Lear still offers a problem for investigation” (p. 3). It may leave a job for traditional theatre historians, but what we can understand from this matter is that we are sure that the texts of King Lear available in the canons today are the results of editions and the sources of the editions might not be the result of Shakespeare's handwriting.

People may also be misled about the originality of Shakespeare since he was also an 'adaptor' like Nahum Tate. Dobson and Wells indicate that Shakespeare adapted King Lear from "The True Chronicle History of King Leir and his Three Daughters, . . . [which was] published in 1605 but written at least fifteen years earlier (2001, p. 244. See also, Lowers, 1968, pp. 6-7). The sub-plot about "Gloucester and his sons is based on episodes from Sir Philip Sidney's Arcadia” (p. 244). More surprisingly, "details of, especially, Edgar's speeches as Mad Tom derive from Harsnett's Declaration, and Florio's Montaigne also influences the play's vocabulary" (p. 244). This information gives us the knowledge that Shakespeare is not necessarily different from Nahum Tate. While Nahum Tate adapted Shakespeare, he adapted from somebody else before him.

Another aspect worth noticing is the intended audience of King Lear during Shakespeare's time (Elizabethan), Nahum Tate's time (Restoration) and Post-restoration (Modern). During the Elizabethan period, there were two kinds of theatres: private and public. The private theatres were designed for the aristocratic audience and the public theatres were for the general public (Brockett, 1995, p. 164). Two of the public theatres, The Theatre and The Globe, were used by Shakespeare's company (p. 167). It informs us that Shakespeare's plays were catered to the public taste of his time, thus he was a popular dramatist. Since Shakespeare was a popular artist who had to deal with the ordinary public taste, not the court, King Lear was a pop culture product. Brockett's statement "much as television dramas are today" (p. 157) when discussing Shakespeare's little thought in preserving his plays also applies to the fact that King Lear and his other plays were products of popular culture of his time.

In the Restoration period, Shakespeare's King Lear to Nahum Tate was King Leir to Shakespeare. On his adaptation of Shakespeare's King Lear for Duke's theatre production in 1681, Tate wrote to Thomas Boteler, 
"(Shakespeare's King Lear was) a heap of jewels, unstrung and unpolished; yet so dazzling in their disorder, that I soon perceived I had sized a treasure" (Tate, 1975, p. ii). Shakespeare's King Lear should be adapted to the tastes of Restoration audience because "the contemporary demand was for good theatre, rather than good drama" (Black in Tate, 1975, p. xvii); that "Restoration play goers also expected a love interest” (p. xviii); and that, quoting Arthur Murphy, "the adaptation would always be most agreeable to an audience" (p. xxvii). Shakespeare was discovered during the Restoration period, but the fact that Tate substantially altered King Lear shows that he (Shakespeare) did not gain authority he does nowadays.

The advent of the modern period really marked the rebirth of Shakespeare. It was started with the effort modern critics made in 'restoring' Shakespeare. For instance, in H. Naville Davies' series of King Lear publications, G. K. Hunter gives introductions which discuss the process of 'restoration' from Tate's King Lear to Charles Kean's revision in 1858. He quotes George Coleman (1970) who attempted "to reconcile the catastrophe of Tate in the story of Shakespeare" (p. vi) in the 1768 version. (Although Hunter suggests that this version was still heavily Tate's). The 'restoration', he contends, is just the ending. 'The text used is largely Tate's text which suddenly switches to Shakespeare in the final scene” (p. vi). Finally, although he mentions that Tate's influence was still present in Kean's revision in 1858, Hunter argues that it was "Shakespeare's" text in the sense that almost all Tate's writing has been removed (p. iv). This re-composition changed the productions of King Lear to a new terrain. Since then, Shakespeare's King Lear has been considered as a classic and, with his other plays, has become the permanent residents of the canons. At the height of modern drama/theatre, in the middecades of the $20^{\text {th }}$ century, when English literature critics were keen on building literary canons, Shakespeare won the most prestigious positions.

\section{The Shifting Fields: the Rises and Falls of Shakespeare's and Tate's Authority}

There is no doubt that Shakespeare is the most well known figure in modern literary and theatre worlds until today. Probably, no writer has had authority higher than his. If he were alive until today, he would probably be a person whose symbolic and cultural capitals in the field of cultural 
production equal any top capitalist in the field of economic production. Since fields of productions, although they have different logics, may overlap, Shakespeare would easily transfer his symbolic and cultural capitals into economic or any other capitals. Nahum Tate, on the other hand, is nobody at the present day. We could bet that even English Department students, the future literary artists or critics, do not know him. If he were alive today, he would be a dwarf compared to Shakespeare and, at best, he would probably work for Shakespeare. People do not know that in his time he was no less authoritative than Shakespeare. To understand this matter, we need to see the shifting fields of cultural productions in which these two figures have acquired or lost their authorities. As Bourdieu puts it, authority is never the product of an individual but that of the field of production. Authority, to put it simply, is the product of an artist's relationships with other artists, dealers/publishers, clients/customers, critics, and the public. However, what "makes authorities" is not each of them, but all of them in relationships which "is the field of production" (1993, p. 78).

To see Shakespeare's and Nahum Tate's authorities, we shall start by examining Shakespeare's field when he was alive. Unlike today, in Shakespeare's time in England, theatre companies, called acting troupes, were strictly regulated by the government. In 1574, to be able to perform, an acting troupe must have a license (Brockett, 1995, p. 160). As Brockett notes, however, local governments sometimes refused 'professional' acting troupes to perform in their areas for reasons such as "danger of plague, the rowdiness of the crowds, and drawing persons from work or religious practices” (p. 160). From this information we can infer at least two things; first of all, unlike the court theatres, the public or professional theatres did not have good relationships with, to add one of Bourdieu's categories, the local governments. Professional theatre's position in the society, therefore, was marginal especially viewed from the religious practices in England. In such a society, a theatre figure like Shakespeare must not have been a very respectable person. In the eyes of other artists, however, Shakespeare might have had certain authority. In the First Quarto of King Lear which was issued in 1608, it was written:

Master William Shakespeare has historye-of King Lear, as yt was played before the Kinges maiestie at White-hall vppon Sainct Stephens night at Christmas Last, by his maiesties servants playinge visually at the Globe on Banksyde ... (in Lowers, 1968, p. 1). 
It seemed that Shakespeare did gain recognition among other artists although as Brockett notes, "in his own days, ...., Shakespeare's critical reputation was lower than that of Johnson or Beaumont and Fletcher (1995, p. 157). Thus, although he was an actor, writer, and even share holder of a troupe (p. 156), he did not have an authority as gigantic as he does posthumously in modern time. He might have gained respect from other artists, he could have produced his own plays since he was a share holder of a troupe, yet critics did not praise him as high as the other three figures. Moreover, he worked more for public theatres which were under the scrutiny of the government and the church. In such kind of field of production, there is little doubt to say that Shakespeare did not posses a substantial authority.

Despite the fact that critics in his time did not appreciate him much, Shakespeare, or rather his friends, left a legacy: his works, or some works attributed to him, were discovered by playwrights after him. About a quarter century after his death, from 1642 to 1660, English theatre activities were stamped out by the Puritans. In 1660, when Charles II was restored to the throne (thus, started the restoration period), theatres were reopened. In the beginning of this period, since the theatre world was not active for almost twenty years, there was a problem of repertoire. Therefore, they produced pre-restoration plays especially the works of Beaumont and Fletcher (pp. 233-237). “Several of Shakespeare’s plays were revised to bring them into line with contemporary tastes” (p. 237). Among the 'revisers' or in today's term 'adaptors' of Shakespeare's works was Nahum Tate. It is necessary to notice that during Tate's time, Shakespeare was not as popular as Beaumont and Fletcher; and while their works were not revised, Shakespeare's were.

One of the plays that were often produced with substantial revision was King Lear. The 'adaptor', Nahum Tate, got a lot of attention for 'finding the unpolished jewel' in 1681. "From 1681 to 1838 in England, and to 1875 in America, all performances adopted or modified Nahum Tate's adaptation, which cuts around 800 lines, modernizes the language, omits the Fool and France, adds a love story between Edgar and Cordelia, and preserves the lives of Kent, Gloucester, and Lear" (Dobson \& Wells, 2001, p. 247). Fifty years after his death, Samuel Johnson (in Dukore, 1974), agreeing with Tate's revision, wrote in 1765 that the public had decided that Cordelia should live. He further wrote: 
Cordelia, from the time of Tate, has always retired with victory and felicity. And, if my sensations could add anything to the general suffrage, I might relate, I was many years ago so shocked by Cordelia's death, that I know not whether I ever endured to read again the last scenes of the play till I undertook to revise them as an editor" (p. 418).

King Lear was probably Shakespeare's most interesting play to $18^{\text {th }}$ century readers/spectators because, as Johnson put it, it so much agitated their passions and interested their curiosity (p. 417). However, since it violated their ideas of justice, Shakespeare's ending was for them too much to bear. It was because the contemporary (Restoration) demand was for good theatre, rather than good drama (Black, 1975, p. xvii); whereas Tate's adaptation "is excellent theatre" (p. xvii).

We now learn that since the Restoration period, the field of production changed. The government's influence was still strong, but it was more in relations to the contemporary political life. As the restoration playwrights were able to write their plays, most of them comedies, their plays started to replace the pre-restoration period. Some plays from the Elizabethan period, however, like King Lear, were revised to suit the public taste. This gave room for Nahum Tate to gain his authority as a playwright. Tate's 'adaptation' was well liked by the restoration public, the producers, and the critics alike. For the Restoration public, Tate was probably like Shakespeare who adapted King Leir to the Elizabethan public. Tate won 'the circle of belief' even after his death for the adaptation. This was proven by the fact that his 'adaptation' was played for one and a half centuries, and "a drama which lives in theatre for one hundred and fifty years cannot be ignorantly dismissed with a shrug and a sneer. The reason for such vitality must be seriously pondered and examined" (Bloom, 1966, p. cvii). Bloom even argues that "even now many productions are chopped and cut, and honey-combed to boot with gags of meanest wit" (p. cvii).

In the modern period, however, Bloom's statement was just a marginal cry. It was because of the new humanitarian project in the English landscape. It started in the nineteenth century when England started the industrialization. The English thinkers considered that the industrialization resulted in the degradation of the English life with the waves of urbanization and the rising number of the working class. For this situation, "George Gordon, early Professor of English Literature at Oxford, 
commented in his inaugural lecture that 'England is sick, and ... English literature must save it'” (Eagleton, 1996, p. 20). The one who answered this call, among others, was a figure named Mathew Arnold (1822-1888). "Arnold saw English culture as seriously threatened by a process of secularization . . . by the rise of a self-important, money-oriented, and utterly conventional middle class" (Bertens, 2001, p. 2). The cure for this sickness, to Arnold, (1880) was literature:

More and more mankind will discover that we have to turn to poetry to interpret life for us, to console us, to sustain us. Without poetry, our science will appear incomplete; and most of what now passes with us for religion and philosophy will be replaced by poetry (as quoted in Bertens, 2001, p. 2).

From this point on, literature became an important subject and English (literature) grew as a field of study so that gradually English Departments were established. Eagleton (1996) discusses Arnold's ideas and its implementation in English universities as follows:

The urgent social need, as Arnold recognizes, is to 'Hellenize' or cultivate the philistine middle class, who have proved unable to underpin their political and economic power with a suitably rich and subtle ideology. This can be done by transfusing into them something of the traditional style of the aristocracy, who as Arnold shrewdly perceives are ceasing to be the dominant class in England, but who have something of the ideological wherewithal to lend a hand to their middle-class masters. State-established schools, by linking the middle class to 'the best culture of their nation', will confer on them 'a greatness and a noble spirit, which the tone of these classes is not of itself at present adequate to impart' (p. 21).

Eagleton sees something ideological in the project, but Arnold and his fellow essentialists would see it as a noble call. To work on this project, since literature became a major, there was a need to find good literature as object of study. One way of doing it is by rediscovering 'the classics', among others was Shakespeare.

The rediscovery of Shakespeare seemed to meet a problem since there were so many manuscripts attributed to Shakespeare. The study of 
Shakespeare grew steadily to the twentieth century such that "no playwright's work has been more fully studied” (Brockett, 1995, p. 156). The essentialist minds, therefore, felt the need to find the 'real' texts of Shakespeare. In doing so, they would readily consider Nahum Tate's King Lear a "hodge-podge" (Black in Tate, 1975, p. xv). A new field of production was started and in this new field of production, Shakespeare was transformed into a giant. His authority grew in such a way that no other figure in modern literature could match it. Since the beginning of the modern period artists, critics, publishers, producers and the public are orchestrating to hail Shakespeare. Yet, we might need to listen to Eagleton (1996) when he says:

Great literature is the product of Great Men, and its value lies chiefly in allowing us intimate access to their souls. There are several problems with such a position. . . . Even if I do have access to Shakespeare's mind when reading Hamlet, what is the point of putting it this way, since all of his mind that I have access to is the text of Hamlet? Why not just say instead that I am reading Hamlet, as he left no evidence of it other than the play itself? Was what he 'had in mind' different from what he wrote, and how can we know? Did he himself know what he had in mind? Are writers always in full possession of their own meanings? (p. 41).

If we extend further Eagleton's questions, we could ask, in the case of King Lear, how can we be so sure that there was an original text that derived from his mind? If the originality of the texts themselves is still disputed, then, why should we bother to search for the original? The modern field of production, however, has made him great.

Perhaps Shakespeare himself, his friends and actors, did not talk about his plays in ways which we would regard as literary critical . . . [Modern] literary criticism selects, processes, corrects and rewrites texts in accordance with certain institutionalized norms of the 'literary' - norms which are at any given time arguable, and always historically variable (p. 177). 
More than just the critics, the other agents, fortunately for Shakespeare, also play in 'the circle of belief' around Shakespeare although it should be noted that:

Shakespeare was not great literature lying conveniently to hand, which the literary institution then happily discovered: he is great literature because the institution constitutes him as such. This does not mean that he is not 'really' great literature - that it is just a matter of people's opinions about him - because there is no such thing as literature which is 'really' great, or 'really' anything, independently of the ways in which that writing is treated within specific forms of social and institutional life (pp. 176-177).

Whether or not Eagleton refers to Bourdieu, he is talking about the fact that literature is great not because of a great figure of any other figure alone, but it is because of the field of the cultural production which makes it so.

\section{CONCLUSION}

In this paper we have tried to see a work of art in the context of the field of cultural production. By discussing Shakespeare's and Tate's King Lear, we can reveal the idea that both works and their writer's authority is actually "nothing other than 'credit' with a set of agents who constitute 'connections' whose value is proportionate to the credit they themselves command" (Bourdieu, 1993, p. 78). On the other hand, in the modern field of production, whether they are aware or otherwise, the essentialists who work on Shakespeare hold the basic belief that there is a 'true' Shakespearean text. Some try to discover the text that is the closest to Shakespeare's handwriting, some try to investigate what Shakespeare really said in his works, some others even try to uncover the mystery of who Shakespeare really was. Researchers on Shakespeare adaptations, consequently, tend to take it for granted that all those 'truths' are alreadyor will be-discovered so that they can pay attention to the 'deviations' of the truths. Even those who 'defend' Tate, such as Benjamin Bloom, are under this spell. They fail to recognize that once a historical event is gone, what is left is just the interpretation of it. 
In a more practical sense, they fail to understand that any theatre production is a cultural production. Both Shakespeare and Tate worked for such a cultural production, and both of them got the 'endorsement' or, in Bourdieu's word, 'credit' from their societies as their patrons. Shakespeare was one of the 'pop' writers of his time, as Tate surely was. The ones who make Shakespeare a godly figure and Tate a dwarf are modern agents in the modern field of production with their own values as filter. John Dryden and Samuel Johnson preferred Tate's text to Shakespeare's. Does it make them fools?

Words such as original, deviation, or even deterioration, therefore, are questionable. Until now we do not know for sure who Shakespeare was and whether the texts attributed to him are his 'original' crafts. Had Shakespeare lived until Restoration period, would not he have done the same thing to his own works as Tate did? The answer to this question is hypothetical, as uncertain as the conclusions made by traditional historians about who Shakespeare was or what he meant in his works.

Viewed from a certain viewpoint, Tate has been 'othered' within modern field of production's discourses. In Brockett's totalized narrative, as it has been aforementioned, his name is not recorded. The question is, "what makes him fail in modern canonization selection?" It is because Tate's works are bad (again, according to whom?) or is there 'political' considerations behind it? To Eagleton, there is an ideology behind it as a background. In the modern field of production context, the writing of history often involves the creation of myths. Shakespeare has been the biggest myth the history of the English theatre/drama has ever made. Tate's adaptation of King Lear, especially, had been once very popular until it kept Shakespeare's from the stage for about one and a half centuries. Putting this fact into the grand narrative of the theatre history might 'hurt' the creation of the myth and, thus, the modern field of production has pushed it into the periphery.

\section{REFERENCES}

Bertens, H. (2001). Literary theory: The basics. London: Routledge.

Bloom, B. (Ed.). (1966). Shakespeare adaptations. New York: B. Bloom.

Bourdieu, P. (1993). The field of cultural production: Essays on art and literature. New York: Columbia UP. 
Brockett, O. G. (1995). History of the theatre ( $7^{\text {th }}$ ed.). Boston: Allyn \& Bacon.

Davies, H. N. (1969). (Ed.). The history of king Lear: 1768. London: Cornmarket P.

Dobson, M., \& Wells, S. (2001). The Oxford companion to Shakespeare. Oxford: Oxford UP.

Eagleton, T. (1996). Literary theory: An introduction (2 ${ }^{\text {nd }}$ ed.). Oxford: Blackwell.

Hieatt, A. K. (1996). English literature. In Microsoft Encarta 97 encyclopedia (p. 20) [Computer Software].

Hibbard, G. R. (1982). King Lear: A retrospect, 1939-79. In K. Muir, \& S. Wells (Eds.), Aspects of king Lear (pp. 1-10). Cambridge: Cambridge UP.

Hunter, G. K. (1970a). Introduction. In H. N. Davies (Ed.), King Lear: R.W. Ellison 1820 (pp. i-xiv). London: Cornmarket P. . (1970b). Introduction. In H. N. Davies (Ed.), King Lear: Cumberland's edition c. 1830 (pp. i-xii). London: Cornmarket P. . (1970c). Introduction. In H. N. Davies (Ed.), King Lear: Charles Kean 1858 (pp. i-xii). London: Cornmarket P.

Johnson, S. (1974). General observations on king Lear. In B. F. Dukore (Ed.), Dramatic theory and criticism (pp. 417-418). Fort Worth: H. B. Jovanovich College P.

Lowers, J. K. (1968). King Lear notes. Lincoln, Nebraska: Cliff Notes.

Shakespeare, W. (1979). King Lear. In O. G. Brockett, \& L. Brockett (Eds.), Plays for the theatre: An anthology of world drama. New York: Holt, Rienhart, and Winston.

Tate, N. (1975). The history of king Lear. Lincoln: University of Nebraska P. 